\title{
Utopia, compaixão e liberdade em Leonardo Padura
}

Maria Analice Pereira da Silva ${ }^{1}$

Resumo: entre os dois romances de Leonardo Padura - $O$ homem que amava os cachorros (2013) e Hereges (2015) - há pontos de contato no que se refere tanto aos temas quanto a alguns dos personagens. O objetivo deste artigo é, portanto, desenvolver uma análise-interpretação desses romances, partindo-se da discussão acerca de temas primordiais neles desenvolvidos, que são, em linhas gerais, os seguintes: o tema da compaixão, no primeiro romance - por meio da voz narrativa; e o tema da liberdade, no segundo - por meio das ações dos personagens. Ambos os romances são ambientados em Cuba e se aproximam, também, quanto à época da história da Ilha neles representada: incluindo-se o período revolucionário, chegando até os anos 2000. O destaque para os temas da compaixão e da liberdade tem a ver, sobretudo, com esse espaço-tempo desenvolvido nos romances, como parte essencial de suas arquiteturas narrativas.

Palavras-chave: Cuba; História; Romance; Leonardo Padura.

\section{Utopia, compassion and freedom in Leonardo Padura}

\begin{abstract}
When considering Leonardo Padura's novels - O homem que amava os cachorros (2013) and Hereges (2015) - we may find some contact points between them, both concerning their themes, and some of their characters. This article aims, therefore, at developing an analysis/ interpretation of these novels, focusing at a discussion on the themes which are developed. Such themes are: the theme of compassion, in the first novel - by means of the narrative voice itself; and the theme of freedom, in the second one - by means of the characters' actions. Both novels take place in Cuba, and they are close to each other if we consider the period of time which they represent, including the revolutionary period, up to 2000 . The emphasis on the themes of compassion and freedom may be explained, mainly, by the period of time developed in the novels, as being essential in the narrative architecture.
\end{abstract}

Keywords: Cuba; History; Novel; Leonardo Padura.

Artigo recebido em: 12/02/2016

Artigo aprovado para publicação em: 09/05/2016

\footnotetext{
${ }^{1}$ Doutora em Letras pela UFPB e Professora do Instituto Federal de Ciência e Tecnologia da Paraíba (IFPB). Email: marianalice@ hotmail.com
}

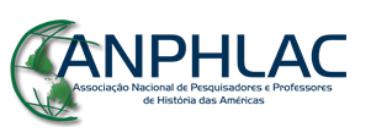

Revista Eletrônica da ANPHLAC, ISSN 1679-1061, №. 21, p. 66-89, Jul./Dez., 2016.

http://revista.anphlac.org.br 


\section{Introdução}

Analisar e interpretar os temas da utopia pervertida e da compaixão, em $O$ homem que amava os cachorros, dadas as nuanças que o envolvem, é como analisar e interpretar, também, o tema da liberdade. A relação entre esses temas é, portanto, intrínseca, em que um diz dos outros dois, visto que as questões apresentadas pelo personagem-narrador Iván se assentam na utopia que se perverte, pois esta tolhe, sobretudo, a liberdade, causando, assim, o medo e, consequentemente, o ódio, que se converte em compaixão e, por fim, no caso específico do personagem Iván, o remorso por sentir essa mesma compaixão.

Destaca-se no romance, justamente, essa falta de liberdade, instalada no período pósrevolucionário cubano, ou, para usar um termo ainda mais apropriado, o período "castrista", no qual a produção cultural, intelectual ou artística estava sob a égide de um processo ocorrido no "quinquênio gris" - 1971/1975 - ou "década gris", e conhecido como parametrización, conforme assinala a professora Sílvia Cezar Miskulin:

\footnotetext{
A nova política cultural foi fundamentada na parametrización da cultura cubana, fenômeno que estabelecia parâmetros ideológicos e morais, que deveriam direcionar a conduta dos intelectuais. O diretor do Consejo Nacional de Cultura, Luis Pavón Tamayo, passou a impulsionar uma "campanha de saneamento", na qual muitos intelectuais e artistas foram expulsos de seus postos de trabalho, ou caíram no ostracismo, foram silenciados, acusados de terem "conduta imprópria" ou de "diversionismo ideológico", ao se aplicar as resoluções do Primeiro Congresso Nacional de Educação e Cultura. (MISKULIN, 2009, p. 236)
}

Essa falta de liberdade, portanto, tem consequências bastante significativas, sobretudo nos seus aspectos culturais e sociais, que são amplamente romanceados nos dois livros. E, no caso do romance Hereges, em particular, esses temas (utopia pervertida, compaixão e liberdade) são recorrentes, mas com ênfase no último: liberdade.

Importante notar que, além dos temas, há dois elementos, dentre outros, também recorrentes nos dois romances e que contribuem, em certa medida, para a configuração das ações romanescas: os personagens Iván e Mario Conde. Ambos são amigos e compartilham de um mesmo ideário sobre a sociedade cubana do período revolucionário e pós-revolucionário.

\section{CANPHLAC}

Revista Eletrônica da ANPHLAC, ISSN 1679-1061, №. 21, p. 66-89, Jul./Dez., 2016.

http://revista.anphlac.org.br 
Iván é protagonista em O homem que amava os cachorros e Mario Conde é protagonista em Hereges. Um, portanto, visita o outro, como bons e velhos amigos: no primeiro romance “[...] meu amigo e congênere Mario Conde [...]”. (PADURA, 2013, p. 505); no segundo romance - "Já adulto, leitor e aspirante a escritor, havia pensado que algum dia gostaria de visitar Paris e, principalmente, viajar pela Itália, como também sonhara seu falecido amigo Iván”. (PADURA, 2015, p. 483)

Esses dois personagens se aproximam em grande medida no que se refere à representação do tema da liberdade nos dois romances. A amizade entre eles se dá no campo do enunciado, uma vez que, como já foi dito, um revisita o outro ou ambos são recorrentes nos dois livros, mas também no campo da enunciação, em que, por suas características pessoais em relação às suas personalidades e ideias, eles são contemporâneos e compartilham um espaçotempo semelhante quanto às questões sociopolíticas cubanas.

Analisar e interpretar a forma como esses temas são representados nesses romances é o objetivo desse artigo, restringindo-se, no entanto, a apenas alguns de seus elementos, haja vista que ambos constituem romances de muito fôlego, tanto no que se refere aos seus elementos estruturais quanto ao conteúdo (ou seja, o chão-histórico) neles configurados. Ambos os romances apresentam em suas arquiteturas narrativas ampla galeria de personagens; alternância de focos narrativos; espaços e tempos narrativos que incluem um longo período da história de Cuba, abrangendo (no caso de Hereges) quase todo o século XX, chegando até os anos 2000.

\section{2. $O$ homem que amava os cachorros: quando ódio se converte em compaixão}

Qualquer coisa em mim pede eternamente compaixão - e chora sobre si como sobre um deus morto, sem altares no culto, quando a vinda branca dos bárbaros moceou nas fronteiras e a vida veio pedir contas ao império do que ele fizera da alegria.

(O livro do desassossego, Fernando Pessoa)

\section{CANPHLAC}

Revista Eletrônica da ANPHLAC, ISSN 1679-1061, №. 21, p. 66-89, Jul./Dez., 2016.

http://revista.anphlac.org.br 
A arquitetura do livro $O$ homem que amava os cachorros se desenha da seguinte maneira: há três histórias centrais que se entrelaçam - duas no passado, que correspondem a uma só, pois envolve Trotski e Ramón; e outra no presente, que envolve Iván e Jaime López. Na história que acontece no presente, a verdadeira identidade de Jaime López, o homem dos cachorros e que Iván encontra por acaso na praia de Santa María del Mar, em Cuba, nos anos 1970, é revelada como sendo mais um dos nomes falsos de Ramón Mercader, assassino de Trotski, e também protagonista da história que acontece no passado. Essa tessitura narrativa conta, também, com um elemento fundamental, que é a metalinguagem, sobretudo ao final do livro, quando aparece uma segunda voz narrativa, no último capítulo, cujo título é por si só representativo: Réquiem, porque, a essa altura da história, Iván, voz primordial da narrativa, é falecido.

$\mathrm{Na}$ posição de personagem cubano, o também narrador Iván parece conferir legitimidade à narrativa quanto aos fatos relativos à história da sociedade cubana que envolve as décadas de 1970/80/90 e 2000. Em que sentido? No sentido de oferecer ao leitor, pela ficção, episódios históricos dos quais fazem parte personagens históricos, cujas ações têm proporções e alcances imensuráveis porque são bastante significativos.

Importante destacar que não se pretende, com esta análise, classificar o romance de Padura como um romance histórico ou mesmo julgar essa ficção quanto ao seu compromisso com os fatos históricos. Pretende-se inferir que Padura romanceia episódios históricos e marcantes do século XX. Necessariamente, ele não faz história. Ou, pelo menos, não é sob esse prisma que ele é lido nesta análise que ora se apresenta, haja vista considerar-se que esse tipo de leitura pode ser um tanto reducionista, pois abre mão de uma grande complexidade no livro: os elementos estéticos e/ou técnicos da própria narrativa. Noutras palavras, considera-se uma leitura do livro como literatura cujo compromisso, em termos tanto de forma quanto de conteúdo, é com questões literárias, mesmo que se aproprie da história (com H maiúsculo) e também sem abrir mão dos seus "condicionamentos sociais", ou seja, dessa mesma história com H maiúsculo.

\footnotetext{
${ }^{2}$ CANDIDO, 2000. Nesse estudo, Candido distingue a sociologia do sociologismo e a análise formal da análise dos condicionamentos sociais como fatores externos, concedendo ao leitor uma compreensão mais profunda do que vem a ser a análise crítica, propriamente dialética. Trata-se, portanto, de um método de análise de base materialista e desdogmatizada, no sentido de verificar as relações dialéticas entre literatura e sociedade, considerando, inclusive, o caráter arbitrário dessas relações, analisando os condicionamentos sociais não de forma unilateral, mas como mecanismos estéticos que "enformam" a matéria.
}

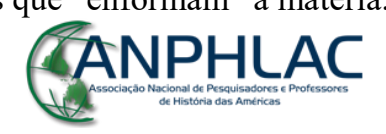

Revista Eletrônica da ANPHLAC, ISSN 1679-1061, №. 21, p. 66-89, Jul./Dez., 2016.

http://revista.anphlac.org.br 
O fato é que Padura se arvora de uma forma literária que lhe dá amplas condições para construir a história do(s) homem(ns) que amava(m) os cachorros. A forma romance, certamente, é que lhe dá essas possibilidades de fluir, seja por águas claras e transparentes, seja por águas turvas. Cabe às necessidades da própria fabulação, da arquitetura narrativa criada pelo autor, escolher este ou aquele procedimento narrativo. O romance, portanto, representa uma importante forma literária no sentido de responder a essas necessidades internas de fabulação. Vejamos o que diz Marthe Robert sobre essa forma literária:

\begin{abstract}
Quanto ao mundo real com que mantém relações mais estreitas que qualquer outra forma de arte, permite-se-lhe pintá-lo fielmente, deformá-lo, conservar ou falsear suas proporções e cores, julgá-lo; pode até mesmo tomar a palavra em seu nome e pretender mudar a vida exclusivamente pela evocação que faz dela no seio de seu mundo fictício. Se fizer questão, é livre para se sentir responsável por seu julgamento ou sua descrição, mas nada o obriga a isso: nem a literatura nem a vida pedem-lhe contas da forma como explora seus bens.

[...] Assim, diferentemente do gênero tradicional, cuja regularidade é de tal ordem que é não apenas submetido a prescrições ou proscrições, como feito por elas, o romance não tem regras nem freio, sendo aberto a todos os possíveis, de certa forma indefinido de todos os lados. É esta evidentemente a razão principal de sua expansão contínua, e também a de sua voga nas sociedades modernas, às quais se assemelha, quando não por seu espírito inventivo, por seu humor buliçoso e vitalidade. (ROBERT, 2007, p. 14)
\end{abstract}

Seria adequado considerar que essa liberdade de expressão, possibilitada pela forma romanesca, é a que Padura desenvolve na confecção de sua matéria e que, mesmo assim, tratase de um romance histórico? Talvez, pelo que preconiza também György Lukács (2011) em sua tese sobre o romance histórico e, mais especificamente, sobre o realismo na literatura, mesmo que se esteja tratando de um período específico de produção romanesca, longe no tempo de ser a que é contemporânea a nós.

$\mathrm{Na}$ apresentação do livro $O$ romance histórico para a tradução brasileira, Arlenice Almeida da Silva discorre sobre o que vem a ser o realismo na literatura, nos termos considerados por Lukács na discussão de sua tese:

O realismo só pode ser realizado quando o âmbito da realidade cotidiana média amplia-se na história e permite ao escritor alcançar na arte o páthos da vida privada, ou seja, a sublimação da realidade interior individual até o ponto em que ela se funde em ações concretas, não em abstrações. (LUKÁCS, 2011, p. 24)

\title{
CANPHLAC
}

Revista Eletrônica da ANPHLAC, ISSN 1679-1061, №. 21, p. 66-89, Jul./Dez., 2016.

http://revista.anphlac.org.br 
Podemos afirmar, mesmo que sumariamente, que assim procede Padura em seu romance: considerando a sua intencionalidade quanto à realidade que propõe representar; alcançando o páthos da vida privada, tanto de Trotski, quanto de Ramón; e, acima de tudo, de Iván e seus compatriotas.

O escritor, de um modo geral, ao criar sua obra, obrigatória e necessariamente, não firma um contrato com a realidade ou uma realidade por ele representada. Isso depende das necessidades internas de cada obra, do projeto literário do autor, enfim, da sua intencionalidade. Já no processo de leitura, o leitor pode estabelecer esse contrato, naturalmente, na sua relação com o livro, seja por identificação ou não, em que se deflagra o que Walter Benjamin (1994) chama de "Sentido da vida" no estudo sobre o narrador de Nikolai Leskov. Nesse estudo, Benjamin discorre sobre a ideia de que o romance, ao contrário da narrativa (referenciando a narrativa tradicional oral), "não pode dar um passo além daquele limite em que, escrevendo na parte inferior da página a palavra fim, convida o leitor a refletir sobre o sentido de uma vida" (BENJAMIN, 1994, p. 213, grifo do autor). É justamente no final do livro de Padura, no último capítulo, intitulado Réquiem, que percebemos essa ideia de Benjamin. É nesse capítulo que morre Iván, o herói (problemático, num termo lukacsiano ${ }^{3}$ ) dessa história e, para continuar a narrativa, seu amigo Daniel domina a narração: num réquiem composto pelo amigo Daniel, que toma para si o fio narrativo e arremata a história narrada por Iván, com um gosto amargo sob o qual a define como "utopia pervertida". É daí que surge o remorso pelo sentimento de compaixão apresentado por Iván e que Daniel demonstra ao final do livro.

Isso resulta, no entanto, da configuração de três elementos narrativos (personagens, narrador, forma/conteúdo) pelos quais é possível verificar de que maneira o narrador vai construindo sua narrativa no limiar entre sentimentos tão adversos, porém complementares, nesse romance: ódio e compaixão. De que maneira? Adentrando na interiorização que o

\footnotetext{
${ }^{3}$ SILVA, 2009. O termo "herói" é aqui empregado tendo por base as reflexões de Lukács em sua Teoria do romance (s.d.), na qual o pensador se vale de orientações da filosofia histórica, sobretudo no que concerne às ideias de Hegel sobre estética para traçar sua discussão sobre a forma romance em oposição à epopeia. Para Lukács, as formas literárias nascem de um processo histórico-filosófico: a epopeia, por exemplo, é considerada uma forma acabada e fechada em seu tempo porque sua matéria principal diz respeito às aventuras de heróis num passado histórico e, portanto, fechado; já o romance, ao contrário, é considerado uma forma inacabada e aberta porque sua matéria primordial é o momento histórico presente, portanto, aberto e inacabado, o que faz com que seu herói seja problemático porque, ao contrário da epopeia, que representa a matéria social de uma comunidade, embora por meio de um herói individual, no romance a matéria primordial é o destino de um indivíduo, mas enquanto individualismo e não, exatamente, o destino de uma comunidade.
}

\section{CANPHLAC}

Revista Eletrônica da ANPHLAC, ISSN 1679-1061, №. 21, p. 66-89, Jul./Dez., 2016.

http://revista.anphlac.org.br 
narrador realiza em cada um dos personagens; apresentando-os não como uma descrição superficial de ações, mas procurando aprofundar-se na psicologia, considerando possíveis meandros e contradições.

Iván é, portanto, o porta-voz responsável por essa tessitura, pois, além de narrar, ele também protagoniza a história, não a história mais central (da Revolução Russa, envolvendo Trotski e Ramón Mercader), mas a sua história de vida pessoal, vivida em Cuba pós-revolução, da censura e dos racionamentos, que não deixa de ser também uma história central. Ou seja, na arquitetura narrativa desse romance, há duas histórias centrais: uma do narrador e outra contada por um narrador. São histórias que se interdependem, completam-se e têm como fio condutor a metalinguagem, já que Iván, ao passo que conta, também mostra questões relativas a esse contar.

É possível verificar que na formalização da vida privada dos homens representados nesse livro há uma similaridade com o jogo de xadrez, pelo qual podemos depreender que o jogador que dá o xeque-mate é justamente aquele que comanda a ótica maior, ou seja, Iván, o narrador-personagem. Utilizando-se justamente de meios pelos quais é possível alcançar alguma verdade, Iván, no decurso da narrativa, arma seu jogo de forma a colocar cada um dos personagens, pela maneira como descreve suas ações e reflete sobre seus comportamentos, em posição de análise e julgamento, em que, praticamente, nenhum escapa. O seu xeque-mate se dá na revelação de um humanismo em que cabem, perfeita e simultaneamente, os sentimentos de ódio e de compaixão. Ao arrumar sua posição no tabuleiro, Iván vai demonstrando, ao longo da narrativa, de que lado está. Dos trotskistas? Dos stalinistas? Dos cubanos? Ou das pessoas enquanto indivíduos e comandadas por um regime político totalitário? Importante notar que, a partir da margem em que se encontra Iván, por meio da qual ele narra a trama, o seu olhar sobre os fatos se formaliza dialeticamente, ou seja, demonstra sempre as várias faces de uma mesma situação. A síntese a que ele chega é justamente aquilo que aqui caracterizamos como xequemate. É assim essa posição à margem que lhe permite refletir sobre um chão histórico bastante complexo também.

Obviamente que o leitor vai, ao longo da trama, identificando o partido tomado por Iván. Porém ao final do livro os argumentos utilizados para justificar a sua posição não apenas surpreendem o leitor, mas o colocam em estado de suspeição, e, tudo isso, graças à técnica narrativa, à arquitetura do livro. Nesse caso, em especial, destaca-se o recurso do narrador como

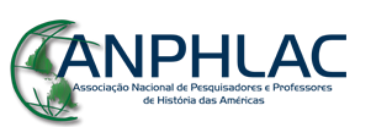

Revista Eletrônica da ANPHLAC, ISSN 1679-1061, №. 21, p. 66-89, Jul./Dez., 2016.

http://revista.anphlac.org.br 
força motriz e o que está em seu entorno: foco, ótica, pessoa do discurso etc. E é interessante notar, também, que não se trata exatamente de uma forma de narrar inovadora ou iconoclasta. Pelo contrário, é possível verificar nesse narrador uma presença marcante daquele narrador benjaminiano em seu aspecto tradicional: aquele que

[...] figura entre os mestres e os sábios. [...] seu dom é poder contar sua vida; sua dignidade é contá-la inteira. O narrador é o homem que poderia deixar a luz tênue de sua narração consumir completamente a mecha de sua vida. (BENJAMIN, 1994, p. 221).

A dimensão humanista de que tratamos aqui é justificada na tirada de mestre ao final do livro, sendo, portanto, o que definimos como xeque-mate:

E as pessoas? Algum deles [dos heróis aqui representados] pensou alguma vez nas pessoas? Perguntaram-me, perguntaram a Iván, se concordávamos em adiar sonhos, vida e todo o resto até que se evaporassem (sonhos, vida e o raio que o parta) no cansaço histórico e na utopia pervertida? (PADURA, 2013, p. 584)

É-nos ratificado, desse modo, o lugar epistêmico desse narrador por meio da narração de um interlocutor seu (o amigo Daniel). É a partir desse lugar que se demonstra o ódio e a compaixão, o remorso e o amor, que também é tema central nesse livro: amor de mãe, de amante, de amigo, de camarada e, como o próprio título mostra, amor pelos cachorros.

É importante verificar, no entanto, que, referente ao personagem Ramón Mercader, o tratamento desse sentimento do amor se dá por via contrária, ou seja, pela sua falta, representado por diversas maneiras, mas, sobretudo, por meio de duas personagens icônicas de extrema importância para a configuração desse personagem no que tange a aspectos da sua personalidade: Caridad (sua mãe) e África (seu amor juvenil). Não por acaso, também, essas mulheres têm os nomes que têm. Mas o que vem ao caso aqui é refletir, senão freudianamente, pelo menos em termos de representação literária, sobre a clara e determinante participação dessas mulheres na vida de Ramón Mercader e, consequentemente, no sentimento de compaixão de Iván. Noutras palavras, podemos definir esse ponto analisado como uma questão de forma narrativa em sua aliança intrínseca com o conteúdo representado.

A compaixão de Iván pelos personagens, mas, sobretudo, por Ramón Mercader, declarada ao final do livro, arrebata o leitor pelas próprias palavras do narrador: asco e remorso pela compaixão que sente por um assassino, por alguém que se entrega ao ato de matar e para

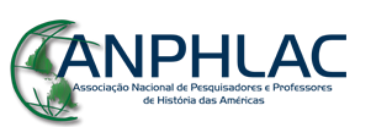

Revista Eletrônica da ANPHLAC, ISSN 1679-1061, №. 21, p. 66-89, Jul./Dez., 2016.

http://revista.anphlac.org.br 
o qual se prepara friamente. É aqui portanto que reside uma questão crucial e que torna grandioso (porque humanístico) esse romance: essa frieza não é tão fria assim porque ela tem causas, tem razões de ser e de existir e, no final das contas, é tudo isso que vem à tona pela voz potente de um narrador que se alterna entre primeira e terceira pessoa e que é onisciente, tem domínio do que fala porque conhece por dentro, conhece nas entranhas.

Destrinçando melhor o que aqui se analisa, vejamos, por meio de um pequeno diálogo, aliás, uma pergunta que Caridad faz a seu filho Ramón e, em seguida, a resposta do filho e as considerações do narrador acerca do que está sendo tratado nessa conversa:

[...] - Ramón, você seria capaz de renunciar a essa mulher?

Ele pressentira que uma pergunta assim poderia chegar e seria a mais difícil de responder.

- O que Kotov quer? - Insistiu, esquivando-se da resposta.

- Já disse, que você renuncie a tudo o que durante séculos nos disseram que era importante apenas para nos escravizar.

Parecia que Ramón estava escutando África. Era como se as palavras de Caridad brotassem da mesma torre do Kremlin, das mesmas páginas de $O$ Capital de onde saíram as de África. E nesse instante teve noção do silêncio que os envolvia há vários minutos. Caridad era África, África era Caridad, e a renúncia a tudo o que tinha sido era-lhe agora exigida como um dever, enquanto aquele mutismo doloroso e frágil pousava sobre sua consciência, transportando o temor de que no próximo minuto seu corpo pudesse ser arrebentado pelo obus, pela bala, pela granada ainda escondida mas já destinada a destruir sua existência. Ramón compreendeu que receava mais o silêncio do que os rugidos perversos da guerra e desejou estar longe daquele lugar. Foi nessa altura que disse, sem saber que dependurava sua vida naquelas poucas palavras:

- Sim, diga-lhe que sim. (PADURA, 2013, p. 58).

Se não pode amar as pessoas, Ramón Mercader, sob o nome de Jaime López, “ama os cachorros", com os quais passeia pela praia de Santa María del Mar em Cuba, já doente e depois de ter cumprido pena em prisões mexicanas pelo assassinato de Trotski e ter voltado à Rússia. E esse amor pelos cães é também apresentado nas figuras de Trotski e de Iván, tratando-se assim de um amor que se justifica pelo elo que envolve os três heróis na trama, mas cada um por razões e de maneiras diferentes.

Além disso, amar os cachorros, mote aproveitado no título do romance, também faz referência a outro título: um conto de Raymond Chandler publicado em Killer in the rain e que Iván leva à praia de Santa María del Mar para ler enquanto aguarda o pôr do sol. É nesse momento que ele tem o primeiro contato com Jaime López, a quem se referirá como "o homem que amava os cachorros", dada a coincidência de Jaime López (o homem que habita a pele de

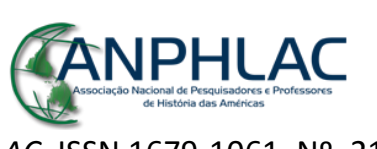

Revista Eletrônica da ANPHLAC, ISSN 1679-1061, №. 21, p. 66-89, Jul./Dez., 2016.

http://revista.anphlac.org.br 
Ramón Mercader) estar passeando na praia com seus dois borzóis no momento em que Iván lê o livro. Vejamos o que diz o personagem Iván em diálogo com o amigo Daniel que domina a narração no último capítulo do romance, quando declara a maneira como (re)conheceu Ramón Mercader:

\footnotetext{
- Sabe como eu tive a certeza de que López era Mercader, antes mesmo de ler esses papéis e ver a fotografia? [...] A chave foi a forma como tratava seus cachorros e como olhava para o mar. Era Mercader em busca da felicidade que sentira em Sant Feliu de Guíxols. Seu paraíso perdido... Cuba foi um placebo. (PADURA, 2013, p. 578)
}

Destaca-se aqui, portanto, a compaixão como uma das questões centrais do romance, sobretudo porque decorre, principalmente, de uma "utopia pervertida", numa forma de desculpar as pessoas, culpando outras, ou mesmo um sistema. E a utopia é pervertida porque constituiu, teoricamente, uma revolução prometida, um futuro promissor e livre e que, em sua práxis, demonstrou exatamente o contrário.

A relação entre história e ficção, apresentada no início desta discussão, não diz respeito exatamente à verificação do grau de veracidade que Padura aponta via ficção, nem tampouco a adentrar em questões éticas sob um ponto de vista do julgamento da posição do autor ou mesmo do que está enunciado no romance. Todavia, já se levantou essa polêmica quando da ocasião do lançamento do livro, entre intelectuais cubanos e de outros países latino-americanos, o que não deixa de ser, também, algo importante a se verificar, dado o nível das argumentações contrárias ou favoráveis à obra de Padura.

É, portanto, até possível e interessante verificar algum teor ético no romance sob mais de um ponto de vista. E discutimos sobre ética, conforme Diana Klinger (2014) discute, ampla e profundamente, considerando-a sob o ponto de vista do sujeito leitor e não do objeto livro, ou da posição do autor, e verificada pelo próprio livro. Noutras palavras, é possível inferir das reflexões de Klinger uma compreensão de ética a partir da perspectiva do leitor e não dos autores que ela analisa; que a ética está na leitura da força, da potência de uma "escrita como dispositivo existencial" (BOLAÑO apud KLINGER, 2014, p. 185). Para sistematizar seu raciocínio, Klinger apresenta, na filosofia que vai de Descartes e Deleuze a Guattari, questões relacionadas a uma discussão sobre desejo e esperança ([im]potência), alegria e lucidez (sabedoria), aceitação do real e fabulação (criação de um "povo de falta”). A partir dessas

\section{GANPHLAC}

Revista Eletrônica da ANPHLAC, ISSN 1679-1061, №. 21, p. 66-89, Jul./Dez., 2016.

http://revista.anphlac.org.br 
discussões, a autora define o que vem a ser a força a que ela se refere: uma força que não está só e exatamente na fabulação ou nos versos que se lê, pois

A literatura não é uma força, mas é preciso transformá-la numa força. [...] É preciso cuidar do cão que morde dentro. Não se deixar domesticar pelo espetáculo excessivo do mundo, não aceitar a chantagem das pequenas ambições cotidianas. É preciso muita força para ser nômade ou bárbaro. Para andar. É preciso força para se deixar vencer pelo desejo. Mas que força é essa e que infância? É esse "ser em demasia", como diz Marona? É preciso muita força para se deixar vencer, como Orfeu, pelo desejo de ver, mesmo que por um instante, o rosto do amor, o rosto da morte. É preciso força para voltar para casa, tanto como para não voltar. É preciso força para esquecer como para lembrar, Lu, para abrir caminhos e para apagar pegadas, para escutar as estrelas mudas, e é preciso força para não afundar. (KLINGER, 2014, p. 191)

A partir dessa discussão sobre a força provocada por e no texto literário, conforme apresenta Klinger, pode-se entender que a leitura de $O$ homem que amava os cachorros convoca o leitor, por meio dessa força por ele encontrada na leitura do romance, a refletir sobre o "sentido da vida" (BENJAMIN, 1994), deixando-se seduzir pelo sentimento de ódio de Daniel, bem como pelo sentimento de compaixão, mas também, não menos, de ódio, de Iván.

- O que se meteu aqui - disse, apontando para a cabeça raspada. - Quando li esses papéis e tive uma ideia mais precisa do que Ramón Mercader tinha feito, senti asco. Mas senti também compaixão por ele, pela forma como o tinham usado, pela vergonha que lhe provocava ser ele mesmo. Já sei, era um assassino e não merece compaixão, mas, porra, não consigo evitar! [..] tinham lhe tirando tudo, o nome, o passado, a vontade, a dignidade. E, no fim das contas, pra quê? Desde que disse a Caridad que sim, Ramón viveu numa prisão que o perseguiu até o dia da própria morte. Nem queimando o corpo todo conseguiria libertar-se da sua história... [...] E, se eles o mataram, não se pode sentir por ele outra coisa que não seja compaixão. E essa compaixão nos faz sentir sujos, contaminados pelo destino de um homem que não deveria merecer nenhuma piedade, nenhuma pena. Por isso me recuso a acreditar que sua própria gente o tenha matado: de alguma forma, isso iria transformá-lo num mártir... e não quero publicar nada porque só de pensar que essa história possa fazer alguém sentir um pouco de compaixão me dá vontade de vomitar.

Observei meu amigo e senti que finalmente começava a compreender alguma coisa. Sua vida (se chegaram a esta altura da história já sabem) tinha sido um rosário de desgraças e frustrações imerecidas mas inevitáveis, tantas e ao mesmo tempo tão comuns que parece inacreditável que em cima de um único homem tenha caído todo o peso de seu tempo e de sua circunstância: foi como se lhe coubesse receber cada um dos golpes que correspondiam a uma geração de crédulos por obrigação. Como se não bastasse, vivera com aquela história de merda no íntimo durante quase trinta anos e tivera a desgraça de que Ana, o que de mais limpo lhe acontecera na vida, reproduzisse com a sua morte o suplício final de Ramón Mercader, sendo obrigado a assistir, dia após dia, a uma agonia que não podia deixar de recordar-lhe a de um assassino desprezível e desprezado. Mesmo assim, junto com a indignação, Iván sentia compaixão por aquele homem e pelo seu destino, e esse sentimento provocava-lhe um intenso rancor contra si mesmo. (PADURA, 2013, p. 579-580)

\section{GANPHLAC}

Revista Eletrônica da ANPHLAC, ISSN 1679-1061, №. 21, p. 66-89, Jul./Dez., 2016.

http://revista.anphlac.org.br 
Essa compaixão, nascida de sentimentos adversos como o ódio, decorre da compreensão humanista que Iván tem dos heróis (heróis-problemáticos ou anti-heróis, em termos lukacsianos) dessa história, os quais, mesmo em sua posição de algozes, desenvolvem ações e conclamam reflexões que enformam a matéria romanesca, que é a representação literária de uma utopia que se perverteu, conforme apresenta o personagem Daniel no seguinte trecho:

\begin{abstract}
Soube então que para muitos da minha geração não seria possível sair incólumes daquele salto mortal sem rede. Éramos a geração dos crédulos, a dos que romanticamente aceitaram e justificaram tudo com os olhos postos no futuro, a dos que cortaram cana convencidos de que deviam cortá-la (sem cobrar, evidentemente, por aquele trabalho infame); [...] a geração que sofreu e resistiu aos embates da intransigência sexual, religiosa, ideológica e cultural e até alcoólica apenas com um gesto de cabeça em muitas vezes sem se encher de ressentimento ou do desespero que conduz à fuga, esse desespero que agora abria os olhos dos mais jovens e os levava a optar pela fuga mesmo antes de levarem o primeiro pontapé na bunda. Tínhamos crescido vendo (era este o grau de miopia) em cada soviético, búlgaro ou tchecoslovaco um amigo sincero [...] tínhamos vivido sob o lema, tantas vezes repetido em cerimônias escolares, de que o futuro da humanidade pertencia por completo ao socialismo (àquele socialismo que, quando muito, só nos parecera um pouco feio, esteticamente, e só esteticamente, grotesco e incapaz de criar, digamos, uma canção com a metade da beleza de "Rocket Man" ou com um terço de "Dedicated to the One I Love" [...] Também não fazíamos a menor ideia de quem tinha sido Trotski ou porque o tinham matado, ou das infames combinações subterrâneas e até evidentes da União Soviética com o nazismo e com o imperialismo, [...] patenteado pela genialidade do Grande Condutor do Proletariado Mundial, o camarada Stalin, remendado mais tarde por seus herdeiros, defensores de uma rígida ortodoxia que usaram para condenar a menor dissidência do cânone que suportava seus desmandos e suas megalomanias. Agora, com muito custo, conseguíamos compreender como e por que toda aquela perfeição havia desmoronado quando só tinham sido deslocados dois tijolos da fortaleza: um acesso mínimo à informação e uma ligeira mas decisiva perda do medo (sempre o bendito medo, sempre, sempre, sempre) que dera consistência àquela estrutura. Dois tijolos e veio-se abaixo: o gigante tinha pés de barro e só se mantivera ereto graças ao terror e à mentira... As profecias de Trotski acabaram de cumprir-se, e a fábula futurista e imaginativa de Orwell, em 1984, acabou se transformando num romance descaradamente realista. E nós sem saber de nada... Ou será que não queríamos saber? (PADURA, 2013, p. 504-505)
\end{abstract}

Podemos, assim, concluir que os temas do romance $O$ homem que amava os cachorros, ora analisados (utopia e compaixão), contribuem para uma configuração humanista dos heróis (problemáticos ou anti-heróis) representados pelas figuras de Trotski, Ramón, Iván e até de Daniel.

Cada um desses heróis tem o seu destino individual traçado pela força histórica do seu tempo. O que eles buscam, por meio de suas ações e reflexões sobre esse tempo-espaço romanesco, no fim das contas, é a liberdade; aquela liberdade que lhes foi negada pelas forças

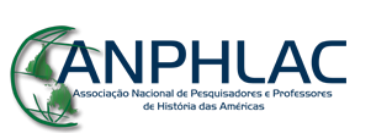

Revista Eletrônica da ANPHLAC, ISSN 1679-1061, №. 21, p. 66-89, Jul./Dez., 2016.

http://revista.anphlac.org.br 
históricas desse tempo de dor, de ódio, e que vai se convertendo em compaixão ao longo do romance, chegando ao seu ápice nas últimas palavras do livro, para além das quais nada mais existe a não ser o convite ao leitor para uma reflexão sobre o "sentido da vida".

\section{Hereges: um ensaio sobre a liberdade}

Liberdade - essa palavra que o sonho humano alimenta: não há ninguém que explique,

e ninguém que não entenda!

(O romanceiro da Inconfidência, Cecília Meireles)

Hereges reúne três histórias que se entrecruzam em um ponto de contato comum: o desaparecimento de um quadro de Rembrandt. O título se deve ao fato de cada história, e de maneira diferente, ser protagonizada por um personagem que, em algum momento de sua vida, rejeitou regras, dogmas e rompeu com paradigmas em prol da possibilidade de ser livre em sentido muito amplo: nos aspectos religiosos ou mesmo na ausência desses aspectos. Noutros termos, diz respeito à crença que os personagens protagonistas têm em certos valores humanos, sendo a liberdade o mais significativo. Esses protagonistas são Daniel, Elias e Judith, conforme aparecem nos títulos dos capítulos.

Duas das três histórias têm como palco principal, ou como espaço-tempo narrativo, a capital cubana e em épocas distintas. A outra, por se tratar de Rembrandt, autor do quadro que dá o mote à trama, passa-se em Amsterdã, no século XVII.

Aqui, o caráter policial se evidencia, não só pela própria trama que gira em torno do desvendamento do paradeiro de um quadro de Rembrandt e do desaparecimento da personagem Judith, mas também por ser protagonizado por Mario Conde, personagem recorrente na obra de Padura, por exemplo, como protagonista na tetralogia intitulada Las cuatro estaciones que

[...] se compone de cuatro novelas: Pasado Perfecto (1991), Vientos de cuaresma (1994), Máscaras (1997) y Paisaje de otoño (1998). En el conjunto de estos libros, Padura hace una revisión de la historia reciente cubana, con el propósito de entender el sentimiento de fracaso de una generación que creció con el proceso revolucionario. Este autor entiende la ficción en términos de hacer las paces con una generación cuya expectativa de un país diferente ha fallado en varios aspectos. Su escritura puede

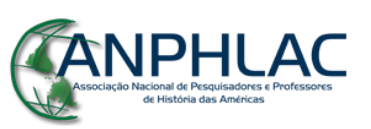

Revista Eletrônica da ANPHLAC, ISSN 1679-1061, №. 21, p. 66-89, Jul./Dez., 2016.

http://revista.anphlac.org.br 
considerarse dentro de lo que Noé Jitrik llama la novela histórica catártica, que acaba con la limitación de que los hechos históricos deben preceder en el tiempo al autor, como lo había planteado Symour Menton.

Las cuatro estaciones

[...] cuentan las aventuras de Mario Conde, teniente investigador de una Central de Investigaciones localizada en La Habana.

[...] Mario Conde opera en el limitado marco de la ley, sin connotaciones revolucionarias. Ya no hay equivalencia entre ley y justicia, y de allí surge una de las fuentes de frustración del personaje. (QUESADA, 2016, p. 142, 170 e 174).

Em Hereges, Mario Conde é o mesmo personagem das histórias policiais que protagoniza e traz consigo, para esse novo romance, alguns de seus amigos e companheiros de trabalho de investigador policial das histórias anteriores. Mas agora, em Hereges, Conde é expolicial que faz a vez de detetive e revendedor de livros usados. Seu amigo Andrés o indica a Elías Kaminsky, filho de um judeu e de uma cubana que se mudaram para Miami na década de 1970. Elías pretende desvendar o mistério em torno do desaparecimento do quadro de Rembrandt, propriedade de sua família.

O primeiro capítulo, intitulado "Livro de Daniel", conta a história de Daniel Kaminsky, pai de Elías Kaminsky. Trata-se de uma família de judeus. E de judeus em Cuba. Para representar a história dessa família, a narração parte do episódio do transatlântico S. S. Saint Louis, que aportou em Havana em 1939 para “depositar sua carga humana de 937 judeus alvoroçados por sua boa sorte" (PADURA, 2015, p. 41), ou seja, refugiados alemães vindos de Hamburgo, fugindo do Holocausto. Os pais de Daniel Kaminsky se encontram nesse transatlântico que é rejeitado por Cuba e também pelos Estados Unidos e Canadá, o que resulta, assim, num "dos mais vergonhosos e mesquinhos [episódios] da política em todo século XX" (PADURA, 2015, p. 42). A família possui, portanto, um quadro de Rembrandt, com imagem de um Cristo muito humano, o que o torna herético. Esse quadro chega ao poder da família ainda no século XVII por meio do rabino Samuel, como forma de pagamento de consultas ao médico Moshé Kaminsky, de quem parte a formação da família Kaminsky.

Essa é a base da história de Daniel Kaminsky, que esteve perto de ver seus pais e irmã, mas, devido à rejeição aos judeus acometida pelo governo cubano, não os vê mais. Daniel decide que se manterá em Cuba junto com seu tio Pepe. Essas notícias relativas a não autorização da entrada de judeus na Ilha pelo governo cubano,

\section{GANPHLAC}

Revista Eletrônica da ANPHLAC, ISSN 1679-1061, №. 21, p. 66-89, Jul./Dez., 2016.

http://revista.anphlac.org.br 
[...] chegavam com a ratificação de uma condenação à morte já anunciada, Daniel Kaminsky, chafurdando nas brumas de sua dor, tomou a drástica decisão de, por vontade própria e do fundo do seu coração, a partir desse instante renegar sua condição de judeu. (PADURA, 2015, p. 57, grifos nossos).

Por renegar sua condição de Judeu, Daniel representa, portanto, o primeiro herege do romance. E o quadro de Rembrandt, herança bastante significativa da família Kaminsky, dado o valor da obra, desaparece em meio a uma trama que envolve muitos outros personagens envoltos em questões comportamentais e também sociais um tanto complexas de um período histórico que vai do final dos anos 1930 aos anos 2000. Elías Kaminsky, filho de Daniel, em 2007 contrata os serviços do ex-policial Mario Conde para descobrir o paradeiro do quadro.

O segundo capítulo, "Livro de Elias", conta a história de Elias Ambrosius, pintor judeu, discípulo de Rembrandt e, possivelmente, dono do rosto que serviu de modelo para o quadro da família de Elías Kaminsky.

Elias Ambrosius é o segundo herege do romance de Padura. Sua história acontece em Amsterdã, no século XVII. Impedido de pintar pelos dogmas de sua religião, Elias se torna discípulo de Rembrandt, de forma clandestina, por três anos. Após a descoberta de seus atos heréticos de pintar, sobretudo de pintar figuras humanas, "Por decreto do conselho rabínico, o processo da muito provável excomunhão de Elias Ambrosius Montalbo de Ávila havia sido marcado para a segunda quarta-feira de janeiro de 1648, na sinagoga dos espanhóis [...]" (PADURA, 2015, p. 312)

Para fugir de tal condenação e prestar contas da vergonha que causou à família, Elias Ambrosius decide rejeitar sua vocação e seu talento para pintor, indo embora de Amsterdã, em busca de um novo possível Messias que se anunciava. Ao se despedir do seu Mestre (Rembrandt), ouve as seguintes palavras, bastante significativas para a configuração do personagem Elias Ambrosius:

'O que aconteceu com você só pode ser visto como uma derrota. E o pior é que não se pode culpar ninguém. Nem a você por ter se atrevido a desafiar certas leis, nem ao seu irmão Amós e aos rabinos por quererem julgá-lo e condená-lo: cada qual está fazendo o que acha que deve fazer, e tem muitos argumentos para fundamentar suas decisões. E isto é o pior: que uma coisa terrível pareça normal para alguns... O que mais me entristece é comprovar que precisam acontecer histórias como a sua, ou renúncias lamentáveis como as de Salom Italia, para que os homens finalmente aprendam como a fé num Deus, num príncipe, num país, a obediência a ordens supostamente criadas para o nosso bem, podem se transformar num cárcere para a substância que nos distingue: nossa vontade e nossa inteligência de seres humanos. É uma derrota da liberdade e...' interrompeu a frase [...]. (PADURA, 2015, p. 319)

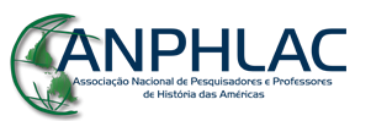

Revista Eletrônica da ANPHLAC, ISSN 1679-1061, №. 21, p. 66-89, Jul./Dez., 2016.

http://revista.anphlac.org.br 
O terceiro capítulo, "Livro de Judith", conta a história de Judith, uma jovem emo, que representa um cenário de tribos urbanas, formadas por jovens que se rebelam, de alguma maneira, contra o que está posto e/ou imposto social, política ou culturalmente. A história se passa na cidade de Havana, em 2008:

\begin{abstract}
Os desastres de que esses garotos haviam sido testemunhas e vítimas geraram indivíduos decididos a se afastar de todo e qualquer compromisso e criar suas próprias comunidades, espaços reduzidos onde encontravam a si mesmos, longe, muito longe, das retóricas de triunfos, sacrifícios, recomeços programados (sempre apontando para o triunfo, sempre exigindo sacrifícios), naturalmente sem contar com eles. (PADURA, 2015, p. 433)
\end{abstract}

Judith representa, portanto, o terceiro herege do romance, não porque rompe ritos e tratados religiosos, pelo contrário, trata-se de uma personagem em profundo conflito quanto à existência de Deus. Sua heresia está mais vinculada à busca da liberdade plena: liberdade de pensar e de ser; de ser emo e lésbica numa sociedade que censura, que tolhe; de poder acreditar na existência de Deus numa sociedade que se diz predominantemente de ateus.

Diferentemente das duas primeiras histórias, em que os protagonistas vivem as narrações, a história de Judith é contada em sua ausência, pois ela é desaparecida e Mario Conde é convocado, já no início do capítulo, a dar conta do seu paradeiro. Essa convocação vem da parte de uma amiga de Judith, que se chama Yadine Kaminsky e, não por acaso, é neta de Ricardo Kaminsky, enteado de Joseph Kaminsky, o tio Pepe de Daniel Kaminsky. Apaixonada por Judith e desesperada pela falta de notícias da amiga, Yadine pede a Mario Conde que busque por Judith. Todo o capítulo se desenvolve, portanto, em torno dessa busca, do início até o final, quando a desaparecida é encontrada morta no fundo de um poço. Essa busca do ex-policial se dá por meio dos amigos, da avó da personagem e da professora Ana Maria, com os quais toma nota das informações sobre Judith: suas convicções, seus gostos, enfim, sua maneira livre de ser.

A história dos Kaminsky e de Judith (comumente nomeada por Judy) se liga por dois fios: um que corresponde ao ideário em torno da condição de herege e outro mais concreto, que é o desaparecimento do quadro de Rembrandt.

Interessante notar que, na primeira página do romance, antes mesmo de se iniciar a narrativa, Padura transcreve o significado de "herege" de alguns dicionários. Vale reproduzir,

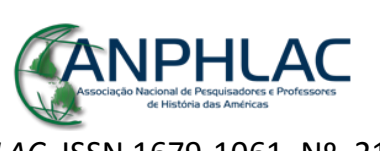

Revista Eletrônica da ANPHLAC, ISSN 1679-1061, №. 21, p. 66-89, Jul./Dez., 2016.

http://revista.anphlac.org.br 
no entanto, o destaque que o autor dá para o significado da palavra no Diccionario de la Real Academia de la Lengua Española, como uso específico em Cuba: "Diz-se de uma situação: [Estar herege] Estar muito difícil, especialmente no aspecto político ou econômico." (PADURA, 2015, p. 15). É nesse significado usual da palavra, dados os elementos espaçotempo da narrativa, que se insere a personagem Judith. Mesmo assim, como representações dos elementos contraditórios em evidência na narrativa, Judith, inspirada pela filosofia nietzschiana (conforme relatos dos amigos, da avó Alma e da professora Ana Maria, com quem mantém relação homoafetiva) da morte de Deus, é levada a um conflito acerca da existência de Deus, o que a faz pensar na possibilidade, também, de deixar de ser emo. Noutras palavras, há um conflito, mas na ordem inversa ao conflito dos outros dois hereges, o que provoca em Mario Conde uma significativa reflexão sobre suas crenças, ou mesmo sobre seu ateísmo:

\footnotetext{
[...] Porque nesses últimos dias aconteceram umas coisas que me fizeram pensar que é mais fácil crer em Deus do que não crer. Olhe, se Deus não existe, nenhum Deus, e os homens estiverem odiando e matando uns aos outros por causa de seus deuses e da promessa de outro mundo melhor... mas se realmente não existe Deus, nem outro mundo, nem nada... Esqueça, Elías, é que ando meio contrariado e dou pra pensar nessas merdas. (PADURA, 2015, p. 419)
}

Esse conflito se justifica pelas condições a que foi submetida a sociedade cubana e sobre as quais o narrador reflete, como, por exemplo, no trecho a seguir: "Tudo isso num país onde o ateísmo havia sido imposto, e o que se colheu, afinal, foi a desconfiança e a ansiedade por outros consolos que a realidade não lhes fornecia" (PADURA, 2015, p. 396). Os demais Daniel Kaminsk e Elias Ambrosius - são hereges na ortodoxia especificamente religiosa, das suas condições de judeus.

Assim como O homem que amava os cachorros, Hereges foi escrito a partir de uma densa pesquisa histórica, tanto no que se refere às questões meramente cubanas (desde a presença de judeus na Ilha e a chegada do transatlântico com refugiados do Holocausto até os dias atuais e a proliferação de tribos urbanas pela cidade de Havana) quanto em relação à história da pintura holandesa, envolvendo também os judeus, no século XVII. Mas a análiseinterpretação aqui empreendida desses dados históricos não os percebe simplesmente como dados históricos. A verdade que interessa aqui é aquela que está a serviço de um projeto primordialmente literário, ou seja, a construção de um romance na sua liberdade plena de se constituir romance, ficção.

\section{CANPHLAC}

Revista Eletrônica da ANPHLAC, ISSN 1679-1061, №. 21, p. 66-89, Jul./Dez., 2016.

http://revista.anphlac.org.br 
Entretanto, esse procedimento analítico não deixa de ser uma via de mão dupla, visto que os temas em destaque para análise conclamam, em certa medida, alguma relação com a realidade histórica, mesmo que seja mais genérica. O leitor pode ser impulsionado, assim, a tomar alguns caminhos, a focar suas reflexões sobre o "sentido da vida", em determinados aspectos, representados e figurativizados por determinados personagens. A análise se centra, dessa forma, em Iván (como já vimos no tópico anterior) e em Judith, do romance Hereges.

A fim de focar a análise na personagem Judith, volta-se, inevitavelmente, aos procedimentos narrativos, responsáveis pela arquitetura do livro. E a um deles em especial: a voz narrativa.

Primeiramente, é importante destacar que Judith é protagonista numa história da qual ela não participa em pessoa: em nenhum momento sua voz é ouvida, nem suas ações aparecem, senão pelas memórias dos demais personagens. A história começa quando a amiga Yadine Kaminsky convoca Mario Conde para procurar Judith, que está desaparecida há dias, mas que, ao fim e ao cabo, já se encontra morta, e os demais personagens só saberão disso ao final do capítulo.

Trata-se, portanto, de um procedimento narrativo no mínimo intrigante, uma vez que o que se sabe da protagonista vem das vozes de outros personagens, bem como do material encontrado por Mario Conde no quarto da jovem, que inclui livros de literatura e de filosofia, CDs de bandas de rock e pôsteres fixados nas paredes, e até as cores dos lençóis. Tudo isso contribui para a figurativização da personagem, no que se refere a seus aspectos tanto físicos quanto psicoemocionais. Mesmo assim, a perspicácia do detetive Mario Conde auxilia na apresentação de determinadas contradições que constituem ponto especial na configuração da personalidade da personagem Judith Torres. E essas contradições só são percebidas pelas entrevistas investigativas que Conde realiza junto aos demais personagens a fim de descobrir o paradeiro de Judith. Trata-se, portanto, de um capítulo polifônico em que todas as outras vozes juntas, como um coro em uníssono, contribuem para a figurativização de Judith, a quem não é dado o direito de se pronunciar em voz narrativa direta (fosse como narradora ou como personagem), dada a sua condição de desaparecida. No entanto, Judy também não está tão silenciada assim. O que essas vozes narrativas proferem vem também das anotações de Judy ou ainda das citações que faz em suas anotações, como, por exemplo, a de Carpentier:

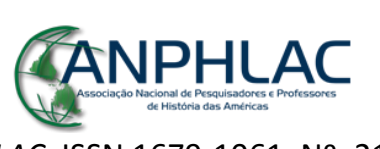

Revista Eletrônica da ANPHLAC, ISSN 1679-1061, №. 21, p. 66-89, Jul./Dez., 2016.

http://revista.anphlac.org.br 
A professora pegou um envelope na pasta e tirou várias folhas manuscritas. Passou algumas e, quando achou o que procurava, leu: "A literatura serve para nos mostrar ideias e personagens como este: '...continuava preso com toda uma cidade, com todo um país como prisão... Só o mar era a porta, e essa porta estava fechada com enormes chaves de papel, que eram as piores. Nessa época se assistia a uma multiplicação, a uma universal proliferação de papéis, cheios de carimbos, selos, assinaturas e reconhecimentos de firma, cujos nomes esgotavam todos os sinônimos de 'licença', 'salvo-conduto', 'passaporte' e quantos vocábulos mais pudesse significar uma autorização para se deslocar de um país a outro, de uma comarca a outra, às vezes de uma cidade a outra. Os almoxarifes, dizimeiros, cobradores de pedágio, alcavaleiros e aduaneiros de outros tempos eram apenas um pitoresco anúncio da mesnada policial e política que agora se aplicava, em toda parte (uns por medo da Revolução, outros por medo da contrarrevolução), a limitar a liberdade do homem em tudo que se referia à sua primordial, fecunda, criadora possibilidade de mover-se na superfície do planeta que lhe coubera habitar... Ele se exasperava, esperneava de fúria ao pensar que o ser humano, renegando seu nomadismo ancestral, tivesse de submeter sua soberana vontade de movimentar-se a um papel'...”. (PADURA, 2015, p. 392)

Citação seguida do comentário de Judy, relembrado pela professora Ana Maria:

- Está escrito para sempre. Também para agora. Judy sabia para que serve a literatura. Porque acrescentou isto - disse, e voltou a ler: - "Se um país ou um sistema não permite escolher onde se quer estar e viver, é porque fracassou. A fidelidade por obrigação é um fracasso". (PADURA, 2015, p. 392)

Todo o romance é narrado em terceira pessoa, mas nesse capítulo, em especial, os comentários do narrador parecem se metamorfosear em alguns trechos em comentários de Mario Conde, dadas as semelhanças entre as duas figuras em termos de ideários, de convicções, enfim, de opiniões sobre as mais diversas questões presentes na narrativa. As mudanças do ponto de vista do narrador para o ponto de vista do personagem Conde em algumas partes são tão sutis que podem confundir o leitor quanto à identificação da voz que está proferindo o enunciado, como se Conde fosse um alter ego do narrador e/ou vice-versa. Por exemplo:

\begin{abstract}
Cruzaram a 17 e, nas imediações de uma das novas e cada vez mais horríveis estátuas de dirigentes latino-americanos construídas para preencher os espaços deixados pelas efígies esvaídas de presidentes cubanos dos tempos republicanos, viram os habitantes da diminuta mas soberana comarca da Emolândia. Os penteados com a mecha lisa chapada contra metade do rosto, as roupas pretas e rosas, aquelas mangas listradas como pele de zebra, os brincos metálicos em diversos lugares da anatomia e lábios, olhos e unhas bastante escurecidos eram os sinais que os distinguiam do resto dos indígenas vistos até aquele momento. Conde, despertando o policial que ainda tinha a contragosto dentro de si, chamou Pombo [...]. (PADURA, 2015, p. 346)
\end{abstract}

Essa similaridade entre narrador e personagem é perceptível, por exemplo, num certo tom de ressentimento que ambos compartilham nos comentários que fazem sobre a situação do

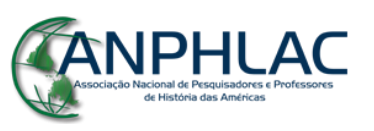

Revista Eletrônica da ANPHLAC, ISSN 1679-1061, №. 21, p. 66-89, Jul./Dez., 2016.

http://revista.anphlac.org.br 
povo cubano, bem como no trato do tema relativo às tribos urbanas. Comparemos os trechos de um comentário do narrador e de um comentário de Mario Conde:

\begin{abstract}
Do narrador:
Os emos eram netos de um avassalador cansaço histórico e filhos de duas décadas de pobreza generalizada, seres despojados da possibilidade de acreditar, empenhados em se evadir para algum canto que lhe parecesse mais propício, talvez até inacessível para todos que estavam fora daquele círculo mental e físico que, sem pensar mais, o expolicial decidiu quebrar. Seguindo um impulso impertinente e irrefreável, Conde deu os três passos mais ágeis que conseguiu nos últimos anos, avançou até onde estava o grupo se sentou entre um emo e uma ema, ou como quer que se chamassem. (PADURA, 2015, p. 347)

De Mario Conde:

- Porra, Manolo, tenho a impressão de que vou fazer cem anos. Para mim não tem pé nem cabeça. Tanto nos encheram a paciência com o sacrifício, o futuro, a predestinação histórica e uma calça por ano para chegar a isso... Vampiros, depressivos e masoquistas por iniciativa própria? Com este calor? (PADURA, 2015, p. 340)
\end{abstract}

Apesar de focos narrativos distintos, os comentários se aproximam no tom com que discorrem sobre o tema. Esse pacto entre essas duas figuras narrativas contribui, ainda, para a configuração do que podemos chamar, também em Hereges, de "utopia pervertida":

\begin{abstract}
Pouco depois do meio-dia, uma manada uniformizada e barulhenta desceu a escada rumo à rua. Escondendo o corpo atrás do tronco rugoso do álamo viu passar Yadine, que se afastou solitária para a Calzada. Observando-a, Conde sentiu um golpe de nostalgia e desencanto: quantos sonhos de futuro acalentados por ele e seus amigos, enquanto desciam aquela mesma rua, haviam virado merda no choque brutal contra a realidade vivida? Inúmeros... (PADURA, 2015, p. 366, grifos nossos)
\end{abstract}

Noutras palavras, a narração é de terceira pessoa, mas não parece tão distanciada como convencionalmente ocorre nas narrações desse tipo. Em alguns momentos, parece ser de primeira pessoa, não simplesmente porque o narrador concede voz ao personagem, mas porque, ao dar voz a ele, também se anuncia. Claro que isso se deve ao recurso da onisciência. Mas nos romances de Padura em questão, esse recurso alcança níveis surpreendentes, tratando-se, assim, de uma técnica em função de uma estética que, contraditoriamente, parece tradicional e inovadora, dada essa transição fluida e quase imperceptível entre os focos narrativos.

Esse procedimento, em seu aspecto técnico, lembra o que se define por autor-implícito, elemento categorizado por Wayne Booth (apud DAL FARRA, 1978) como uma entidade

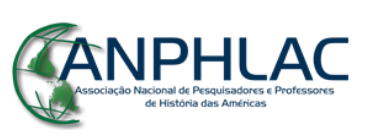

Revista Eletrônica da ANPHLAC, ISSN 1679-1061, №. 21, p. 66-89, Jul./Dez., 2016.

http://revista.anphlac.org.br 
ficcional que se coloca entre o narrador e o autor real, funcionando como uma máscara deste. Vejamos o que diz Maria Lúcia dal Farra sobre o autor-implícito:

\begin{abstract}
Mesmo num romance "impessoal", como o pretende ser aquele de terceira pessoa onde o narrador não tem características específicas, suas "qualidades pessoais" transparecem no grau de visão com que o autor-implícito o dotou, na preferência em fazer falar a uma personagem e calar a outra, no poder de deter os olhos mais sobre uma e "simular" não enxergar a outra. Do jogo entre o ponto de vista do narrador e as próprias "ressalvas" que ele instaurou nascerá a ótica do autor-implícito. (DAL FARRA, 1978, p. 25)
\end{abstract}

Parece oportuno afirmar, portanto, que essa transitoriedade tão fluida e livre entre narrador e personagens, e, sobretudo, o personagem Mario Conde, conflui para a formalização de um dos temas centrais do romance: a liberdade. Noutras palavras, a forma narrativa desenvolvida pelo autor - considerando, inclusive, a existência do autor-implícito que concede às vozes narrativas, sobretudo à de Mario Conde, um livre trânsito entre si, chegando a se confundirem - ajusta-se perfeitamente ao tema central do romance.

Não seria exagero afirmar, portanto, que o romance Hereges pauta sua narrativa num ensaio sobre a liberdade, ou seja, pela ficção, pelos recursos narrativos e ficcionais (ações dos personagens, vozes narrativas etc.), chega-se a uma profunda reflexão sobre as diversas faces do que vem a ser liberdade, dadas as condições de cada um dos personagens que por ela grita: Daniel, Elias e Judith. Liberdade num sentido bastante amplo, pois é liberdade num tempoespaço marcado por diversos tipos de censura: religiosa, social e política. Liberdade representada em forma de grito nas vozes e nos gestos desses personagens hereges e, sobretudo, na voz de Judith, que é a voz que falta e que, ao fim e ao cabo, representa o grito mais alto, silenciado na morte da personagem, no fundo de um poço, às margens da cidade de Havana, portanto, às margens de tudo: das escolhas, dos prazeres, das crenças, dos valores que ela estabeleceu para sua vida; inclusive, a partir das canções que ouviu e das leituras que fez.

\title{
Considerações finais
}

Considerando que $O$ homem que amava os cachorros e Hereges, publicados no Brasil respectivamente em 2013 e 2015, constituem romances de fôlego longo dadas as questões

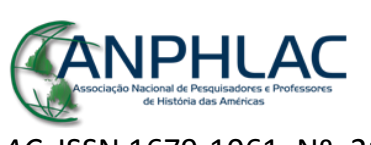

Revista Eletrônica da ANPHLAC, ISSN 1679-1061, №. 21, p. 66-89, Jul./Dez., 2016.

http://revista.anphlac.org.br 
históricas em que eles mergulham, destacando-se, nessa análise, as questões mais relacionadas a Cuba, vale fechar essa discussão trazendo à baila um aspecto importantíssimo no papel exercido pelos narradores desses romances e, em linhas gerais, pela postura do escritor Leonardo Padura: a opção por (re)apresentar uma sociedade a partir de um ponto de vista crítico; noutras palavras, a sua opção ideológica ao adentrar o universo histórico-social de Cuba.

Foi por optar por um olhar mais crítico da sociedade cubana que Leonardo Padura foi acusado, quando do lançamento de $O$ homem que amava os cachorros, por exemplo, de propagar uma visão negativa do país e de seu regime político, ao mostrar ao mundo, pelos pensamentos e ações de seus personagens cubanos, um chão histórico complexo, repleto de contradições, e sem mencionar diretamente episódios importantes da história de Cuba, como o Embargo Econômico dos EUA.

Porém, Padura não faz História; faz ficção. Vale-se da liberdade irrestrita de inventar dada, naturalmente, à figura do romancista, conforme assinala Hayden White (2008) que, ao comparar o trabalho do historiador com o trabalho do romancista, aponta a escolha como um elemento primordial para o historiador, enquanto que, para o romancista, além da escolha, há também fortemente o elemento da invenção. Noutras palavras, o historiador escolhe o modo como vai historiar os fatos, ou seja, o modo para elaboração do enredo (romanesco, trágico, cômico ou satírico); já o romancista, devido à liberdade com que constrói seu enredo, além de escolher, ele inventa.

É, portanto, nesse universo da invenção que reina a arte do escritor, sua criatividade, sua capacidade de contar história. E é nessas atitudes de escolher e de inventar a partir do que se escolhe que estão imbricadas questões ideológicas e, também, éticas.

Por fim, reitera-se que Padura não faz História, mas também não deixa de fazer, uma vez que, mesmo acercado da sua liberdade de inventar, é a um chão histórico real que seus romances se ligam por meio das ações e comportamentos e sentimentos de seus personagens. Se certas posturas e ideários causam incômodo em determinados leitores, é porque tocou neles também o olhar para o real e não exclusivamente para o ficcional. A questão é que essa relação entre realidade e ficção na literatura, de um modo geral, é arbitrária pois, como afirma Hayden White (2008, p. 19): “toda a discussão sobre a natureza do 'realismo' em literatura se embaralha na incapacidade de estabelecer criticamente em que consiste uma concepção genuinamente histórica da "realidade"".

\section{GANPHLAC}

Revista Eletrônica da ANPHLAC, ISSN 1679-1061, №. 21, p. 66-89, Jul./Dez., 2016.

http://revista.anphlac.org.br 
E, afora todas essas questões, o que há de maior qualidade nos romances de Leonardo Padura ora analisados pode não estar exclusivamente nesse fio que liga realidade e ficção e no seu grau de realismo, mas na forma, na estrutura narrativa que o escritor inventou para contar suas histórias e, nessa estrutura, destacam-se, como força motriz, os narradores que o romancista criou, a quem deu vozes, pelas quais o leitor é capaz de adentrar fluida e profundamente em certas complexidades humanas que envolvem significados de posturas e sentimentos essenciais ao ser humano como: utopia, compaixão e liberdade.

\section{Referências bibliográficas}

BENJAMIN, Walter. Obras escolhidas: magia e técnica arte e política. Trad. Sérgio Paulo Rouanet; Prefácio Jeanne Marie Gagnebin. $7^{\mathrm{a}}$ ed. São Paulo: Brasiliense, 1994.

CANDIDO, Antonio. Literatura e sociedade: estudos de teoria e crítica literária. $8^{\mathrm{a}}$ ed. São Paulo: Nacional, 2000.

DAL FARRA, Maria Lúcia. O narrador ensimesmado: o foco narrativo em Vergílio Ferreira. São Paulo: Ática, 1978. (Ensaios, 47).

KLINGER, Diana. Literatura e ética: da forma para a força. Rio de Janeiro: Rocco, 2014.

LUKÁCS, György. O romance histórico. Trad. Rubens Enderle. Apresentação Arlenice Almeida da Silva. São Paulo: Boitempo, 2011.

. Teoria do romance. Trad. Alfredo Margarido. Lisboa: Editorial Presença, s.d. (Biblioteca de Ciências Humanas).

MISKULIN, Sílvia Cezar. Os intelectuais cubanos e a política cultural da Revolução: 19611975. São Paulo: Alameda, 2009.

PADURA, Leonardo. Hereges. Trad. Ari Roitman, Paulina Vacht, com a colaboração de Bernardo Pericás Neto. São Paulo: Boitempo, 2015.

. O homem que amava os cachorros. Trad. Helena Pitta. São Paulo: Boitempo, 2013.

\section{GANPHLAC}

Revista Eletrônica da ANPHLAC, ISSN 1679-1061, №. 21, p. 66-89, Jul./Dez., 2016.

http://revista.anphlac.org.br 
QUESADA, Uriel. Capítulo II - Saldar cuentas con la historia. El caso de Las cuatro estaciones, de Leonardo Padura. Disponível em: 〈https://loyno.academia.edu/UQuesada〉. Acesso em: 13 jan. 2016.

ROBERT, Marthe. Romance das origens e origens do romance. Trad. André Telles. São Paulo: Cosac Naify, 2007.

SILVA, Maria Analice Pereira da. Por que teoria do romance? In: $O$ romance Dois irmãos no ensino médio e no vestibular: uma discussão teórico-metodológica. Tese de Doutorado em Letras - Universidade Federal da Paraíba, Programa de Pós-Graduação em Letras, 2009.

WHITE. Hayden. Meta-história: a imaginação histórica do século XIX. Trad. José Laurênio de Melo. $2^{\text {a }}$ ed. São Paulo: Editora da Universidade de São Paulo, 2008.

\section{GANPHLAC}

Revista Eletrônica da ANPHLAC, ISSN 1679-1061, №. 21, p. 66-89, Jul./Dez., 2016.

http://revista.anphlac.org.br 